\title{
MASS MEDIA EXPOSURE OF INDONESIAN GRADUATE OFFICIALS
}

\author{
Leslie Palmier
}

Though the Indonesian military regime permits a very wide range of private newspapers, magazines, and radio stations (television is a state monopoly), it maintains a close punitive control over them, as demonstrated by the closure in October 1986 of the Jakarta afternoon newspaper Sinar Harapan. (At the time of writing, January 1987, permission had been given for its reappearance, under different managers and under an altered name of Suara Pembaharuan.) Any consideration of the mass media in Indonesia must therefore bear in mind that the information conveyed there may not be reliable or complete, and certain events may not be reported at all.

Nevertheless, given the importance of the bureaucracy, it is of interest to know the extent and nature of exposure of officials, particularly in the senior grades, to the mass media. This may help to identify their sources of continuing information about the world, and thus the background against which their attitudes are formed and decisions made. At the least, an official may read an Indonesian newspaper or magazine regularly just in order to know what he is expected to believe; in itself not unimportant. And, of course, the media are not only domestic.

\section{The Sample}

The surveyl to be related here was limited to graduate officials in the Indonesian government, that is to say all those who held at least the first degree, the Bachelor or Sarjana Muda. According to the State Personnel office (Badan Administrasi Kepegawaian Negara, usually abbreviated to BAKN), the total number of such officials at the time of the survey in 1982 was 231,907 . A systematic random sample of their files yielded 1,001 names. These were sent a questionnaire including inter alia items on mass media exposure. 489 responses were received, not all complete. As may be seen from Table 1 , responses came disproportionately from officials who had higher degrees (mostly the Sarjana), and from slightly older officials, though the division between the sexes was very similar to that of the sample.2

1. The research of which the survey formed part was financed by the British Social Science Research Council and the British Academy, and in Indonesia was greatly assisted by the Office of Educational and Cultural Research and Development of the Department of Education, and by the State Personnel office (BAKN), to all of which go my thanks.

2. Leslie Palmier, "Graduate Indonesian Officials--Occupations Income and Social Origins," Southeast Asian Journal of Social Science 14, 1 (1986): 45-59 at 45 . 
Table 1

Sample of Files and Respondents

\begin{tabular}{|c|c|c|c|c|}
\hline & & Files & Respondents & \\
\hline \multirow[t]{3}{*}{ a) } & Sex & & & \\
\hline & $\begin{array}{l}\text { Male } \\
\text { Female }\end{array}$ & $\begin{array}{l}77 \% \\
23\end{array}$ & $\begin{array}{l}77 \% \\
23\end{array}$ & \\
\hline & & $N=1,001$ & $N=489$ & \\
\hline \multirow[t]{3}{*}{ b) } & Degrees & & & \\
\hline & $\begin{array}{l}\text { Bachelor } \\
\text { Higher }\end{array}$ & $\begin{array}{l}56 \% \\
44\end{array}$ & $\begin{array}{l}52 \% \\
48\end{array}$ & \\
\hline & & $N=1,001$ & $N=481$ & \\
\hline \multirow[t]{4}{*}{ c) } & Age & & & \\
\hline & $\begin{array}{l}22-32 \\
33-42 \\
43+\end{array}$ & $\begin{array}{l}27 \% \\
48 \\
25\end{array}$ & $\begin{array}{l}25 \% \\
44 \\
16\end{array}$ & $\begin{array}{l}25-34 \\
35-44 \\
45+\end{array}$ \\
\hline & & $N=1,001$ & $N=488$ & \\
\hline & Median: $33-37$ & & & $35-39$ \\
\hline \multirow[t]{3}{*}{ d) } & Salary grades & & & \\
\hline & $\begin{array}{l}\text { II } \\
\text { III } \\
\text { IV }\end{array}$ & $\begin{array}{c}69 \% \\
28 \\
3\end{array}$ & $\begin{array}{l}6 \% \\
52 \\
42\end{array}$ & \\
\hline & & $N=981$ & $N=481$ & \\
\hline
\end{tabular}

One may also note that, based on information derived from the sample of files, the salaries of officials who possessed higher degrees were likely to exceed those of Bachelors. Indonesian government regulations specify the salary grades to which holders of Bachelor and Higher degrees are to be appointed; the latter command a considerable premium. As a result of a wide variety of supplements, however, 3 salaries cannot be calculated directly from grades; and sometimes the holder of a Bachelor degree may command a salary greater than that of a colleague on a higher grade. (Total incomes, which include unauthorized additions, are of course even further removed from the grades.) Nevertheless, the grades do provide a convenient indication of relative ranks and, therefore, access to emoluments.

It will be observed from Table 2 that only one percent of those holding a Bachelor's degree were to be found in the highest salary grade, as against 12 percent of the Highers, and that some 77 percent of the latter were in the intermediate grade of III, against only 12 percent of Bachelors. Most of these, in fact, were in the lowest grade of II.

3. Cf. C. Gray, "Civil Service Compensation in Indonesia," Bulletin of Indonesian Economic Studies 15, 1 (March 1979): 85-113 passim. 
Table 2

Salary Grades by Degrees

\begin{tabular}{ccc}
\hline Salary grades & Bachelor & Higher \\
\hline II & $77 \%$ & $12 \%$ \\
III & 22 & 77 \\
IV & 1 & 12 \\
& $N=548$ & $N=433$ \\
\hline
\end{tabular}

Newspapers

Throughout this section, it must be kept in mind that our respondents were government officials and as such had access to newspapers provided by their offices. In other words, reading a certain newspaper does not necessarily imply an individual decision to purchase the daily in question.

As Table 3 shows, the majority of respondents read two or more daily papers, while more than two in five read at least three.

Table 3

Daily Newspapers Read

\begin{tabular}{cc}
\hline Number & Respondents \\
\hline 1 & $27 \%$ \\
2 & 32 \\
3 & 24 \\
4 & 9 \\
5 & 6 \\
$6+$ & 2 \\
& $N=85$ \\
\hline
\end{tabular}

These figures may be analyzed further by sex and level of degree, as in Table 4 below. Those holding only the Sarjana Muda are referred to as "Bachelors"; those with any further degree as "Highers."

Table 4

Newspaper Readership by Sex and Level of Degree

\begin{tabular}{ccccc}
\hline Number read & Men & Women & Bachelors & Highers \\
\hline 1 & $26 \%$ & $30 \%$ & $32 \%$ & $21 \%$ \\
2 & 31 & 34 & 30 & 34 \\
3 & 24 & 20 & 21 & 25 \\
4 & 10 & 7 & 7 & 12 \\
5 & 5 & 7 & 7 & 4 \\
$6+$ & 4 & 2 & 3 & 4 \\
& $\mathrm{~N}=377$ & 108 & 254 & 231 \\
\hline
\end{tabular}


Though the differences between the categories are too small to be of statistical significance, it will nevertheless be noted that the men read somewhat more newspapers than the women. The difference was even greater in favor of the Highers as against the Bachelors. This may no doubt be partiy accounted for by the fact that the men and the Highers tend to be in the more senior and better-paid positions. 4

The respondents read a very great variety of newspapers. However, as indicated in Table 5 (which shows a11 the newspapers read by at least 2 percent of respondents), a majority of respondents read only a minority of newspapers, specifically Kompas, Suara Karya, and Sinar Harapan.

Table 5

Readership of Newspapers

\begin{tabular}{lr} 
Angkatan Bersenjata (Armed Forces) & $3 \%$ \\
Berita Buana (World News) & 3 \\
Kompas (Compass) & 27 \\
Merdeka (Freedom) & 6 \\
Pelita (Light) & 3 \\
Pikiran Rakyat (Popular Opinion) & 4 \\
Suara Karya (Voice of Labor) & 15 \\
Suara Merdeka (Voice of Freedom) & 5 \\
Sinar Harapan (Ray of Hope) & 12 \\
Sinar Pagi (Morning Ray) & 3 \\
Kedaulatan Rakyat (Sovereignty of the People) & 3 \\
Surabaya Post & 2 \\
Others (25+) & 14 \\
\multicolumn{2}{c}{ Total newspapers read }
\end{tabular}

A few words of explanation concerning the major newspapers may be of interest. Kompas is a Jakarta morning paper. Reputed to have been 1 aunched by Sino-Indonesian Catholics, only 12 percent of its readers are Catholics, with 80 percent being Muslims.5 Sinar Harapan was a Jakarta evening paper founded by Batak Protestants. Only 17 percent of its readers, however, were Protestant and 14 percent were Catholics. In contrast with Kompas, only 55 percent of its readers were Mus 1 im. 6 Both these papers have been known for their independence and intellectual quality. Suara Karya is the organ of Golkar, the government supported political party, membership of which is virtually compulsory for all government officials. As the official mouthpiece of the regime, it is of course liberally distributed to a 11 government offices.

The newspapers read by less than two percent of our respondents included such local publications as Waspada (Medan), Bahari (Semarang), Bali Post, and Bandung Post, as well as the English language Jakarta Indonesia Times, not to

4. Palmier, "Graduate Indonesian Officials," pp. 50, 51.

5. P. Burg, "La presse de l'Ordre Nouveau: sa diffusion et son public," Archipel 25 (1983): 7-22.

6. Ibid., p. 14. 
mention very many others. In most cases these dailies were read in addition to those mentioned in the 1 ist above.

It may be useful to consider further the readership among officials of the major newspapers, particularly as we have comparable data on Kompas and Sinar Harapan for the large cities.7 First, the breakdown between male and female readers was as follows:

Table 6

Major Newspapers and Gender of Readers

\begin{tabular}{lcccc}
\hline & Kompas & Sinar Harapan & Suara Karya & Respondents \\
\hline Men & $76 \%$ & $81 \%$ & $81 \%$ & $77 \%$ \\
Women & 24 & 19 & 19 & 23 \\
& $N=315$ & 134 & 177 & 489 \\
\hline
\end{tabular}

In considering these figures it must be borne in mind that some 43 percent of respondents read a11 three newspapers; hence the discrepancy between the totals for the three newspapers and the number of respondents.

It will be noted that the division between the genders of readers of Kompas is very similar to that of the respondents as a whole, while the differences for the other two newspapers are not statistically significant. In brief, neither sex shows a strong preference for any one of the three newspapers. This finding agrees with the earlier survey by Burg with respect to readership of the first two newspapers in the six largest Indonesian cities. 8

We might similarly compare the age profiles of the readers of these three newspapers among our respondents.

Table 7

Age Distribution of Newspaper Readers

\begin{tabular}{ccccc}
\hline Age Group & Kompas & Sinar Harapan & Suara Karya & Respondents \\
\hline $25-34$ & $38 \%$ & $39 \%$ & $36 \%$ & $40 \%$ \\
$35-44$ & 47 & 53 & 49 & 44 \\
$45+$ & 16 & 18 & 16 & 16 \\
& $N=315$ & 134 & 177 & 489 \\
\hline
\end{tabular}

It may here be noted that in the earlier survey some 70 percent of newspaper readers were below the age of 35 (the population of the cities sampled showed

7. Ibid., pp. 8-12.

8. Ibid., p. 12 . 
only 60 percent in the same age group). For our graduate officials, however, the bias is the other way. Sixty percent were aged 35 or more, but the newspaper readers showed an even higher proportion in that age group, the highest being attributed to Sinar Harapan. However, the small numbers involved do not give these differences statistical significance, and they should be regarded as only indicative. It remains true, however, that the graduate officials as a whole were among the older readers of these three newspapers.

A more marked difference between the readership of these three newspapers emerges when we consider the division between Bachelors and Highers, as in Table 8 below.

Table 8

Readership of Major Newspapers by Degrees Held

\begin{tabular}{lcc}
\hline & Bachelor & Higher \\
\hline Kompas & $24 \%$ & $31 \%$ \\
Sinar Harapan & 10 & 14 \\
Suara Karya & 19 & 12 \\
Total newspapers & 304 & 322 \\
\hline
\end{tabular}

These differences are statistically significant, and seem to indicate that holders of higher degrees were more inclined than Bachelors to read Kompas and Sinar Harapan, and less likely to read Suara Karya.

We turn next to consider the ethnic composition of the readership of these three newspapers. Table 9 below takes a respondent's province of birth as indicating the ethnic group to which he or she belongs.

Table 9

Ethnic Composition of Newspaper Readership

\begin{tabular}{lcccc}
$\begin{array}{l}\text { Province of birth } \\
\text { (Ethnic group) }\end{array}$ & Kompas & Sinar Harapan & Suara Karya & Respondents \\
\hline $\begin{array}{llll}\text { Central \& East Java; } \\
\text { Yogyakarta (Javanese) }\end{array}$ & $45 \%$ & $38 \%$ & $45 \%$ & $43 \%$ \\
West Java (Sundanese) & 11 & 5 & 7 & 11 \\
North Sumatra (Batak) & 7 & 16 & 10 & 10 \\
West Sumatra (Minangkabau) & 8 & 7 & 6 & 10 \\
Other provinces (19) & 29 & 34 & 32 & 26 \\
& $\mathrm{~N}=315$ & 134 & 177 & 489 \\
\hline
\end{tabular}

Since 43 percent of our respondents were born in the Javanese homelands indicated above, and 11 percent in West Java, it is no surprise that the percentages for Kompas's readership are very similar. The 1978 survey also found that most regular readers of Kompas in the city populations sampled were Javanese 
or Sundanese, 43 percent and 19 percent respectively.9 It is worth noting however that Suara Karya too enjoys favor among Javanese, though less among the other ethnic groups. Sinar Harapan is both less popular among Javanese, and much more popular among Batak respondents, than either of the other papers.

We may rearrange the figures to consider how each of the four ethnic groups identified distributed its favors among the three newspapers, using the same criteria as those above.

Table 10

Distribution of Newspapers by Ethnic Group

\begin{tabular}{lcccc}
\hline & $\begin{array}{c}\text { Centra) \& East } \\
\text { Java; Yogyakarta } \\
\text { (Javanese) }\end{array}$ & $\begin{array}{c}\text { West Java } \\
\text { (Sundanese) }\end{array}$ & $\begin{array}{c}\text { North } \\
\text { Sumatra } \\
\text { (Batak) }\end{array}$ & $\begin{array}{c}\text { West } \\
\text { Sumatra } \\
\text { (Minangkabau) }\end{array}$ \\
\hline Kompas & $51 \%$ & $63 \%$ & $34 \%$ & $54 \%$ \\
Sinar Harapan & 21 & 14 & 38 & 24 \\
Suara Karya & 28 & 13 & 18 & 22 \\
& $N=278$ & 56 & 64 & 46 \\
\hline
\end{tabular}

These figures suggest that Kompas was particularly popular among sundanese respondents, and still fairly so among Javanese and Minangkabau, but least popular among the Batak. Sinar Harapan came a poor second among the first three ethnic groups, but was the most popular among the Batak, with Kompas a close second. Suara Karya, the Golkar organ, was more favored by the Javanese than by the other groups, but it ran close to Sinar Harapan among the Sundanese and the Minangkabau. It was a clear third choice, however, for Batak readers.

The figures in Table 10, taken together with those of the preceding tables, imply that Kompas and Suara Karya derive most of their readership from the Javanese and Sundanese (i.e., those originating from the island of Java), while Sinar Harapan derived most of its readership from Bataks. Although Sinar Harapan was less favored among the Javanese, it still obtained a substantial part of its readership from them because of their numerical superiority in Indonesia's population. It should however be noted that the differences observed in the two preceding tables are not large enough to claim statistical significance, and they should be regarded only as indicative.

Finally, we consider readership in the light of our respondents' provinces of residence. Table 11 below identifies the provinces where at least 2 percent of readers of one or other newspaper were to be found.

One must first note that there is no statistically significant difference between the distribution of readers of Kompas and that of the respondents as a whole. Nevertheless, there is a marked apathy towards the newspaper by respondents residing in North Sumatra; the only instance, in fact, of more than a percentage point difference between the readership and the respondents.

9. Ibid., p. 15 . 
Table 11

Newspaper Readership by Province of Residence

\begin{tabular}{|c|c|c|c|c|}
\hline Province & Kompas & Sinar Harapan & Suara Karya & A11 Respondents \\
\hline Aceh & $3 \%$ & $1 \%$ & $3 \%$ & $3 \%$ \\
\hline North Sumatra & 3 & 9 & 7 & 8 \\
\hline West Sumatra & 4 & 3 & 2 & 4 \\
\hline South Sumatra & 4 & 1 & 3 & 4 \\
\hline Jakarta & 17 & 24 & 12 & 14 \\
\hline West Java & 17 & 11 & 11 & 16 \\
\hline Central Java & 14 & 13 & 20 & 15 \\
\hline Yogyakarta & 7 & 4 & 5 & 7 \\
\hline East Java & 9 & 11 & 11 & 10 \\
\hline $\mathrm{Ba} i \mathrm{i}$ & 2 & 1 & 2 & 2 \\
\hline South Kalimantan & 2 & 1 & 2 & 2 \\
\hline North Sulawesi & 1 & 5 & 2 & 2 \\
\hline South Sulawesi & 4 & 5 & 5 & 5 \\
\hline \multirow[t]{2}{*}{ Others (14) } & 13 & 11 & 15 & 8 \\
\hline & $N=315$ & 134 & 177 & 489 \\
\hline
\end{tabular}

There is, however, a statistically significant difference between the distribution of both Sinar Harapan and Suara Karya and that of our respondents as a whole. Neither of these newspapers was particularly popular in West Java, despite the province's proximity to Jakarta, where both are published. Sinar Harapan's sale of nearly a quarter of its copies in Jakarta, a much larger proportion than that of our respondents residing there, is accounted for by the fact that as a serious afternoon newspaper it has the field to itself. If we consider the Javanese homelands, i.e., Central Java, Yogyakarta, and East Java together, then Suara Karya was more, and Sinar Harapan considerably less, favored than the respondents' distribution might have suggested. Of interest, too, is Sinar Harapan's relative popularity in both North Sulawesi, with its Christian population, and Islamic South Sulawesi, over either of the other two newspapers. In brief, then, Kompas had a distribution that roughly approximated that of our respondents, and was read by some two-thirds of them; Sinar Harapan, with only 27 percent of our respondents reading it, enjoyed a disproportionately high sale in Jakarta and in North and South Sulawesi, but a correspondingly low one in the Javanese homelands, while Suara Karya, read by 36 percent of respondents, was relatively more popular in the Javanese homelands and less el sewhere.

The similarities between the findings concerning the ethnic origins and province of residence of newspaper readers are perhaps explained by the fact that with regard to North and West Sumatra, and the Javanese homelands, upwards of three-quarters of our respondents were natives of the province in which they resided while this was the case for only a small minority in Jakarta and its adjoining province of West Java.10

10. Lestie Palmier, The Indonesian Intelligentsia, University of Bath, Centre for Development Studies Occasional Paper (Bath, 1984), p. 8. 
Journals and Magazines

Table 12 shows the number of magazines read by our respondents, again distinguishing between their genders and degrees.

Table 12

Number of Magazines Read

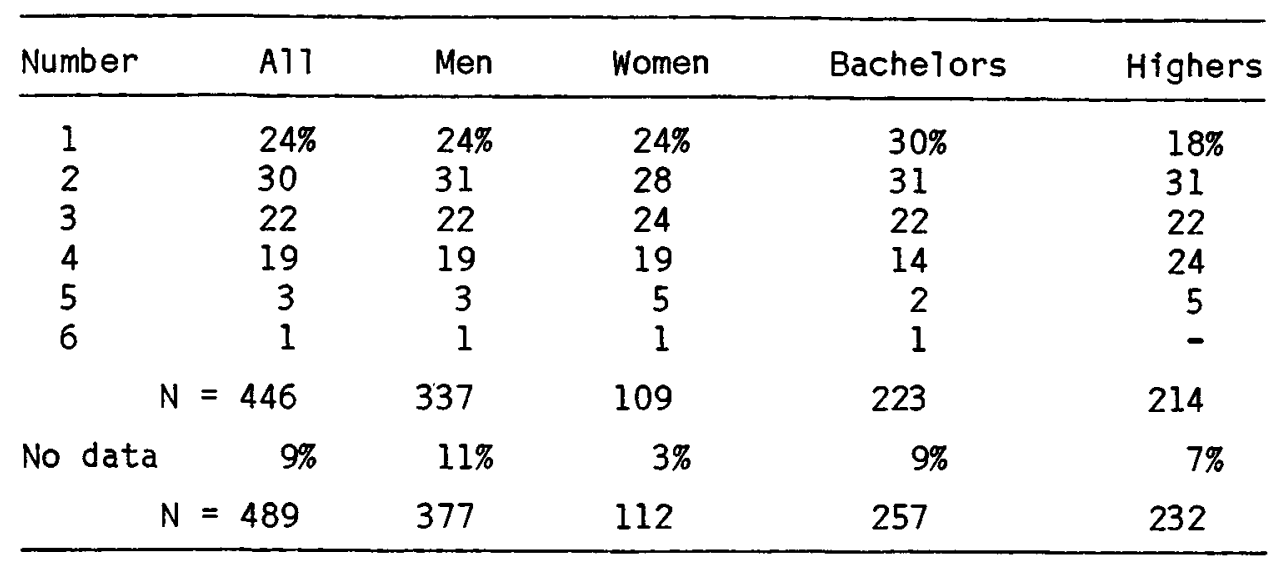

The distinction between men and women is, obviously enough, not statistically significant; that between Bachelors and Highers is. Only 37 percent of Bachelors read more than two magazines but 52 percent of Highers did. Here again, this may be partiy accounted for by the fact that the Highers can afford to buy more. The type of magazines they read, however, is of greater interest. Respondents were asked to give the names of those they read frequently; the first five of these were then coded under the categories given below although, of course, not all respondents mentioned so many. Table 13 indicates the percentages achieved by the different kinds of magazine or journal.

Table 13

Type of Magazines Read

\begin{tabular}{lccccc}
\hline & Al1 & Men & Women & Bachelors & Highers \\
\hline Indonesian newsmagazines & $16 \%$ & $18 \%$ & $10 \%$ & $12 \%$ & $20 \%$ \\
Foreign newsmagazines & 4 & 5 & 2 & 2 & 7 \\
Indonesian vocational & 14 & 15 & 11 & 11 & 17 \\
Foreign vocational & 3 & 4 & 1 & 1 & 5 \\
Women's & 21 & 12 & 48 & 27 & 15 \\
General Indonesian & 35 & 39 & 25 & 41 & 30 \\
General foreign & 1 & 1 & 1 & 1 & 1 \\
Indonesian intellectual & 3 & 4 & 1 & 2 & 4 \\
Religious & 2 & 3 & 1 & 3 & 2 \\
Total magazines mentioned & 1,136 & 852 & 284 & 551 & 585 \\
\hline
\end{tabular}


Quite a large number of magazines were included within these categories. By far the most important Indonesian newsmagazine is Tempo, published in Jakarta. Its readership has increased substantially since 1978, when with a circulation of 72,500 , each copy was read by an average of five people, so that its total readership was of the order of $360,000.11$ The foreign newsmagazines are Time and Newsweek. Several journals are included within the category, Indonesian vocational, which deal with subjects as varied as electronics, the economy, management, and agriculture, as well as a number published by government departments and personnel bodies. The foreign vocational journals are equally varied, but of course do not include "house journals." The two most important women's magazines were Kartini and Femina, in that order. It will be noted that their readership was not restricted to women officials. There is also a great variety of general Indonesian magazines. They are designed to appeal to a 11 members of the family, and include such titles as Selecta (modeled on the Reader's Digest), Panji Masyarakat (Social Banner), Keluarga (Family), Zaman (The Age), Humor Hidup ( $\mathrm{ife}$ ), and Detektif Romantika (Romantic Detective). The foreign general magazine is the Reader's Digest, with Prisma the Indonesian intel lectual organ. All the religious magazines mentioned were Islamic. Hardly unexpected is the evident popularity of the general journals; equally noteworthy, however, is the significant proportion of respondents who read newsmagazines and vocational journals.

The differences between men and women, and between Bachelors and Highers in Table 13 are both statistically significant. Men read more of all magazines, with the sole exception of those concerned with women. Highers, in their turn, read more than Bachelors of all magazines apart from those concerned with women, those of a general character, and the religious publications.

\section{Electronic Media}

With respect to the electronic media, it is perhaps not surprising that graduate officials as a whole proved to be familiar with televiewing; a fact to which their higher salaries are no doubt related. As with previous tables, Table 14 compares men and women on the one hand, and Bachelors and Highers on the other.

Table 14

Frequency of Televiewing

\begin{tabular}{lcccc}
\hline & Men & Women & Bachelors & Highers \\
\hline Not viewing & $2 \%$ & $3 \%$ & $3 \%$ & $1 \%$ \\
Rarely & 2 & 2 & 2 & 2 \\
Sometimes & 21 & 31 & 2 & 20 \\
Usually & 75 & 64 & 69 & 77 \\
& $\mathrm{~N}=375$ & 110 & 255 & 230 \\
No data & $1 \%$ & $2 \%$ & $1 \%$ & $1 \%$ \\
& $\mathrm{~N}=377$ & 112 & 257 & 232 \\
\hline
\end{tabular}

11. Burg, "La presse de T'Ordre Nouveau," p. 15. 
No great statistical significance attaches to the difference between men and women, although the table does indicate that men are more avid viewers than women. The difference between the Bachelors and Highers, however, is significant; though both, it will be noted, are frequent viewers, the Highers are more so, nearly four in five indicating that they viewed as a manner of course.

Two further questions were asked on this topic, one concerned with 1 istening to Indonesian radio, the other about foreign broadcasts.

Table 15

Listening to Indonesian Radio

\begin{tabular}{lcccc}
\hline & Men & Women & Bachelors & Highers \\
\hline Not at a11 & $2 \%$ & $4 \%$ & $1 \%$ & $4 \%$ \\
Rarely & 12 & 9 & 9 & 14 \\
Sometimes & 37 & 39 & 34 & 41 \\
Usually & 49 & 48 & 56 & 41 \\
& $\mathrm{~N}=376$ & 111 & 257 & 230 \\
\hline
\end{tabular}

Here we find that Bachelors are the group with the largest proportion of regular listeners; the Highers show only a moderate interest, less than that of any other group. It is apparent that Highers have a much greater interest in televiewing, no doubt for reasons already mentioned.

Table 16

Listening to Foreign Radio

\begin{tabular}{lcccc}
\hline & Men & Women & Bachelors & Highers \\
\hline Never & $15 \%$ & $18 \%$ & $14 \%$ & $18 \%$ \\
Rarely & 27 & 33 & 26 & 31 \\
Sometimes & 48 & 41 & 53 & 39 \\
Usually & 10 & 8 & 7 & 12 \\
& $\mathrm{~N}=370$ & 109 & 250 & 229 \\
\hline
\end{tabular}

The differences between the four categories are too small to be statistically significant. The general picture, however, is clear enough. Half or more of the respondents declared that they listened to foreign radio occasionally or as a matter of course. Here it may be added that reliable but unattributable sources indicate that the favorite foreign radio broadcasts were from Radio Australia, the British Broadcasting Corporation, the Voice of Malaysia, and the Voice of America, in that order.

To summarize, our sample of graduate officials read with some enthusiasm, not only newspapers but also magazines, and were also avid televiewers as well as listeners to both domestic and foreign broadcasts. The wide circulation 
among them of the relatively independent newspapers, as well as both Indonesian and foreign newsmagazines, together with the exposure to foreign broadcasts, suggests that the officials took the trouble to obtain more than one view of events. We have noted that this tendency is more marked among those with the higher degrees, who hold the more responsible positions. 